\title{
Enhanced trans-Himalaya pollution transport to the Tibetan Plateau by cut-off low systems
}

\author{
Ruixiong Zhang ${ }^{1}$, Yuhang Wang ${ }^{1}$, Qiusheng $\mathrm{He}^{2}$, Laiguo Chen ${ }^{3}$, Yuzhong Zhang ${ }^{1}$, Hang $\mathbf{Q u}^{1}$, Charles Smeltzer ${ }^{1}$, \\ Jianfeng Li ${ }^{1}$, Leonardo M. A. Alvarado ${ }^{4}$, Mihalis Vrekoussis ${ }^{4,5,6}$, Andreas Richter ${ }^{4}$, Folkard Wittrock ${ }^{4}$, and \\ John P. Burrows ${ }^{4}$ \\ ${ }^{1}$ School of Earth and Atmospheric Sciences, Georgia Institute of Technology, Atlanta, GA, USA \\ ${ }^{2}$ School of Environment and Safety, Taiyuan University of Science and Technology, Taiyuan, China \\ ${ }^{3}$ Urban Environment and Ecology Research Center, South China Institute of Environmental Sciences (SCIES), \\ Ministry of Environmental Protection (MEP), Guangzhou, China \\ ${ }^{4}$ Institute of Environmental Physics and Remote Sensing, University of Bremen, Bremen, Germany \\ ${ }^{5}$ Center of Marine Environmental Sciences - MARUM, University of Bremen, Bremen, Germany \\ ${ }^{6}$ Energy, Environment and Water Research Center (EEWRC), The Cyprus Institute, Nicosia, Cyprus
}

Correspondence to: Yuhang Wang (yuhang.wang@eas.gatech.edu) and Qiusheng He (heqs@tyust.edu.cn)

Received: 3 August 2016 - Discussion started: 28 September 2016

Revised: 20 December 2016 - Accepted: 1 February 2017 - Published: 28 February 2017

\begin{abstract}
Long-range transport followed by deposition of black carbon on glaciers of Tibet is one of the key issues of climate research as it induces changes on radiative forcing and subsequently impacting the melting of glaciers. The transport mechanism, however, is not well understood. In this study, we use short-lived reactive aromatics as proxies to diagnose transport of pollutants to Tibet. In situ observations of short-lived reactive aromatics across the Tibetan Plateau are analyzed using a regional chemistry and transport model. The model performance using the current emission inventories over the region is poor due to problems in the inventories and model transport. Top-down emissions constrained by satellite observations of glyoxal are a factor of 2-6 higher than the a priori emissions over the industrialized Indo-Gangetic Plain. Using the top-down emissions, agreement between model simulations and surface observations of aromatics improves. We find enhancements of reactive aromatics over Tibet by a factor of 6 on average due to rapid transport from India and nearby regions during the presence of a high-altitude cut-off low system. Our results suggest that the cut-off low system is a major pathway for long-range transport of pollutants such as black carbon. The modeling analysis reveals that even the state-of-the-science highresolution reanalysis cannot simulate this cut-off low system accurately, which probably explains in part the underestima-
\end{abstract}

tion of black carbon deposition over Tibet in previous modeling studies. Another model deficiency of underestimating pollution transport from the south is due to the complexity of terrain, leading to enhanced transport. It is therefore challenging for coarse-resolution global climate models to properly represent the effects of long-range transport of pollutants on the Tibetan environment and the subsequent consequence for regional climate forcing.

\section{Introduction}

The Tibetan Plateau, commonly referred as the Third Pole and the last pristine land of the Earth, has drawn much attention in environmental and climate research in recent years (Menon et al., 2002). Although Tibet appears to be isolated from industrialized regions due in part to the transport barrier by its being a plateau and its pollutant concentrations being generally low, the Third Pole is vulnerable to regional climate change. Areas of the Tibetan Plateau over $4 \mathrm{~km}$ in altitude are warming at a rate of $0.3^{\circ} \mathrm{C}$ per decade, twice as fast as the global average (Xu et al., 2009). In addition to the increase of greenhouse gases (GHGs) and the associated global warming, black carbon (BC) is likely another important contributor to the warming of the Tibetan Plateau. The deposi- 
tion of BC on the vast glaciers of the Tibetan Plateau will decrease the surface albedo, accompanied by increased sunlight absorption and subsequent enhanced melting (Hansen and Nazarenko, 2004; Ramanathan and Carmichael, 2008; Ming et al., 2009; Yasunari et al., 2010). Increasing BC concentrations have previously been found in ice core and lake sediment records (Xu et al., 2009; Cong et al., 2013). The dwindling of glaciers over Tibet is a major concern for freshwater supply to a large portion of the Asian population through the Indus River, Ganges River, Yarlung Tsangpo River, Yangtze River, and Yellow River (Singh and Bengtsson, 2004; Barnett et al., 2005; Lutz et al., 2014). Though melting glaciers favor river runoff temporarily, mass loss of glaciers endangers water supply during the dry season in the future (Yao et al., 2004; Kehrwald et al., 2008).

Besides narrowing the uncertainties of $\mathrm{BC}$ emissions, aging, and deposition, better understanding the transport pathways is equally important in this region. Surrounded by the largest BC sources of East Asia and South Asia (Bond et al., 2007; Ohara et al., 2007), Tibet is primarily affected by pollutant transport from these two regions (Kopacz et al., 2011; Lu et al., 2012; Zhao et al., 2013; Wang et al., 2015, 2016; Zhang et al., 2015; Li et al., 2016; Kang et al., 2016). Kopacz et al. (2011) attempted to identify the sources of BC over glaciers in the Himalayas and the Tibetan Plateau (HTP) using the adjoint model of GEOS-Chem. Lu et al. (2012) developed a novel back-trajectory model with $\mathrm{BC}$ emissions, hydrophilic-to-hydrophobic aging, and deposition and found that South Asia and East Asia account for 67 and $17 \%$ of BC over the HTP, respectively. Using source tagging, biofuel and biomass burning emissions from South Asia are found to be the largest sources of BC in HTP, followed by fossil fuel combustion emissions (Zhang et al., 2015). Hindman and Upadhyay (2002) suggested that the vertical lifting due to convection and subsequent horizontal mountain-valley wind lead to the transport of aerosols from Nepal to Tibet. Dumka et al. (2010) also stressed the important role of mountainvalley wind in the $\mathrm{BC}$ concentration in the central Himalayas. Cong et al. (2015) suggested that both the large-scale westerlies from South Asia and the local mountain-valley wind from South Asia are major transport pathways. The synopticscale trough and ridge can potentially lead to the trespassing of atmospheric brown clouds from South Asia to the Tibetan Plateau (Lüthi et al., 2015). Ji et al. (2015) indicated that the southwesterlies during monsoon season favor aerosol transport across the Himalayas from South Asia. Aerosol observations in previous studies are mostly limited to the southern and northern slopes of the Himalayas (Hindman and Upadhyay, 2002; Dumka et al., 2010; Cong et al., 2015), with very few in situ sites (e.g., Namco, Linzhi) inside Tibet (Kopacz et al., 2011; Ji et al., 2015; Lüthi et al., 2015; Zhang et al., 2015). Considering the complex topography (Lawrence and Lelieveld, 2010; Ménégoz et al., 2013; He et al., 2014; Kumar et al., 2015) and scarce observations (Maussion et al., 2011), it is crucial to evaluate model-simulated transport per- formance over the Tibetan Plateau using available observations with a good spatial coverage. Observation-constrained modeling is needed to better understand potential model biases due to the uncertainties of model-simulated transport from South Asia to Tibet.

In this study, we use short-lived reactive aromatics as proxies to diagnose transport of pollutants to Tibet. In situ observations of short-lived reactive aromatics across the Tibetan Plateau are analyzed (Sect. 2.1). Anthropogenic emissions including fossil fuel combustion, gasoline evaporation, and solvent use constitute the main sources of atmospheric aromatics (Sack et al., 1992; Fu et al., 2008; Henze et al., 2008; Cagliari et al., 2010; Cabrera-Perez et al., 2016). Biofuel and biomass burning is another important source (Fu et al., 2008; Henze et al., 2008). The main sink of aromatics is $\mathrm{OH}$ oxidation with lifetimes ranging from hours to days (Atkinson, 2000; Liu et al., 2012b). We use satellite observations to minimize the biases of emission inventories for upwind regions of Tibet (Sect. 2.2, 2.3 and 2.4) and then apply a regional chemistry and transport model constrained by highresolution reanalysis meteorological data to understand missing transport processes in model simulations (Sect. 3). On the basis of these results, we examine the implications for global climate modeling studies of anthropogenically driven changes over the Tibetan Plateau (Sect. 4).

\section{Methods}

\subsection{In situ aromatic data}

Whole-air samples were collected in $2 \mathrm{~L}$ electro-polished stainless-steel canisters, which had been cleaned and vacuumed according to the TO- 15 method issued by the US EPA before shipment to the sampling sites. The restricted grab sampler (39-RS-x; Entech), which has a $5 \mu \mathrm{m}$ Silonitecoated metal particulate filter, was placed on the inlet of the canister to completely filter out dust and other particulates during sampling. These samples were taken in daytime from 08:00 to 19:00 LT (Beijing time, GMT +8 ) with an interval of 1 to $2 \mathrm{~h}$. The sampling time was $5 \mathrm{~min}$ to fill the vacuumed canisters. The filled canisters were transported back to the laboratory of the Guangzhou Institute of Geochemistry, Chinese Academy of Science. Each air sample was analyzed for 65 light non-methane hydrocarbons (NMHCs) species. The samples were pretreated by an Entech Model 7100 Preconcentrator (Entech Instruments Inc., California, USA) and analyzed by a gas chromatography-mass selective detector (GC-MSD/FID, Agilent 7890A/5973N, USA) using dual columns and dual detectors to simultaneously analyze both low- and high-boiling-point volatile organic compounds (VOCs) with each injection. The detailed analytical procedure is described by Zhang et al. (2012).

In this study, we analyze 65 measurements of aromatics (benzene, toluene, ethyl-benzene, and m/p/o-xylene) and 
(a)

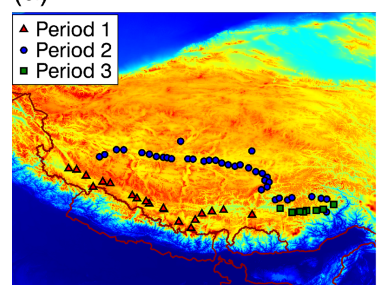

(b)

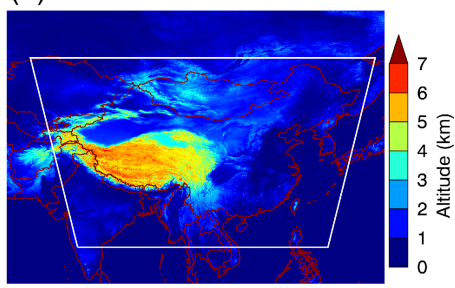

Figure 1. Overview of regions involved in this study. Locations of observations for period 1 (13-17 October 2010, triangle), period 2 (19-24 October 2010, circle), and period 3 (25 October 2010, square) are shown in (a). White polygon in (b) represents the model domain margin of REAM. Altitude data from Global Topographic Data (GTOPO30, courtesy of the US Geological Survey) are shown as colored background.

wind speed measurements taken across Tibet during October 2010 (Fig. 1a). Care was taken in sampling such that there are no direct urban, industrial, or road emissions in the upwind direction of the sampling location. The lifetimes of toluene, ethyl-benzene, and m/p/o-xylene are relatively short (2-20 h), and these reactive aromatic compounds therefore provide observational constraints for transport from India and nearby regions to Tibet. We group the samples into three periods based on the time and locations of the measurements, i.e., period 1 from 13 to 17 October 2010 to the north of the Himalayas along the southern border of Tibet, period 2 from 19 to 24 October across the interior of the Tibetan Plateau, and period 3 of 25 October to the west of the Yarlung Tsangpo Grand Canyon in southeastern Tibet (Fig. 1a).

\subsection{SCIAMACHY CHOCHO measurements}

The SCanning Imaging Absorption spectroMeter for Atmospheric CHartographY (SCIAMACHY) onboard Environmental Satellite (ENVISAT) operated from 2002 to 2012 (Burrows et al., 1995; Bovensmann et al., 1999), with an overpass time at about 10:00 local time. SCIAMACHY made passive remote-sensing measurements of the upwelling radiation from the top of the atmosphere in alternate nadir and limb-viewing geometry. Mathematical inversion of the measurements of SCIAMACHY yields a variety of data products including glyoxal (CHOCHO) vertical column densities (VCDs; unit: molecules $\mathrm{cm}^{-2}$ ). The retrieval uses the differential optical absorption spectroscopy (DOAS) technique (Wittrock et al., 2006; Vrekoussis et al., 2009; Alvarado et al., 2014). The CHOCHO retrieval used in this study is based on the algorithm developed in Alvarado et al. (2014), which includes corrections for the interferences with nitrogen dioxide $\left(\mathrm{NO}_{2}\right)$ over the regions with high $\mathrm{NO}_{x}$ emissions as well as liquid water over oceans (Alvarado, 2016). The detection limit for SCIAMACHY CHOCHO VCD is about $1 \times 10^{14}$ molecules $\mathrm{cm}^{-2}$. The overall monthly uncer-

tainty of CHOCHO VCDs $\left(C_{\mathrm{CHOCHO}}^{\text {SCIAMACHY }}\right)$ in the selected region during October 2010 is given by $\alpha \times C_{\mathrm{CHOCHO}}^{\text {SCIAMACHY }}+$ $1 \times 10^{14}$ molecules $\mathrm{cm}^{-2}$, where the value of $\alpha$ is in a range of 0.1 to 0.3 . Following the method as described by Liu et al. (2012b), we derive a top-down aromatic emission estimate for South Asia constrained by $\mathrm{CHOCHO}$ retrievals described in Sect. 2.4.

\subsection{3-D REAM model}

We use the 3-D Regional chEmical trAnsport Model (REAM) to examine the chemistry evolution and regional transport of aromatics. REAM has been used in previous studies, including large-scale transport (Wang et al., 2006; Zhao et al., 2009b, 2010), vertical transport (Zhao et al., 2009a; Zhang et al., 2014, 2016), emission estimates (Zhao and Wang, 2009; Liu et al., 2012b; Gu et al., 2013, 2014, 2016), and other air quality studies (Zeng et al., 2003, 2006; Choi et al., 2005, 2008a, b; Wang et al., 2007; Liu et al., 2010, 2012a, 2014; Gray et al., 2011; Yang et al., 2011; Zhang and Wang, 2016).

REAM has a horizontal resolution of $36 \mathrm{~km}$ with 30 vertical levels in the troposphere and 5 vertical levels in the stratosphere covering adjacent regions of China (Fig. 1b). The model top is at $10 \mathrm{hpa}$. Meteorological fields in REAM are obtained from the Weather Research and Forecasting model (WRF) assimilations constrained by National Centers for Environmental Prediction Climate Forecast System Reanalysis (NCEP CFSR; Saha et al., 2010) 6-hourly products, which have a horizontal resolution of T382 $(\sim 38 \mathrm{~km})$. We run the WRF model with the same resolution as in REAM with a domain larger than that of REAM by 10 grid cells on each side. Meteorological inputs related to convective transport are updated every $5 \mathrm{~min}$, while the others are updated every $30 \mathrm{~min}$. The recent update of REAM expands the GEOS-Chem standard chemical mechanism (V9-02) to include a detailed description of aromatic chemistry (Bey et al., 2001; Liu et al., 2010, 2012b). Aromatics are lumped into three species based on reactivity, i.e., ARO1 (toluene, ethyl-benzene), ARO2 (m/p/o-xylene), and benzene. The atmospheric lifetimes of the three aromatic tracers against $\mathrm{OH}$ are $18 \mathrm{~h}, 4.2 \mathrm{~h}$, and 3.9 days during the study period (13-25 October 2010), respectively. Due to the long atmospheric lifetime of benzene, it is more difficult to track and identify its sources; thus we do not explicitly discuss benzene in this study. We focus our analysis on reactive aromatics (toluene, ethyl-benzene, and $\mathrm{m} / \mathrm{p} / \mathrm{o}$-xylene).

Initial and boundary conditions for chemical tracers are taken from GEOS-Chem (V9-02) $2^{\circ} \times 2.5^{\circ}$ simulation (Bey et al., 2001). Anthropogenic emissions are from the MIX inventory for October 2010 ( $\mathrm{Li}$ et al., 2017). MIX is a mosaic Asian anthropogenic emission inventory with the Multiresolution Emission Inventory for China (MEIC) and several other emission inventories for other Asian countries. In addition to the MIX inventory, we also conduct sensitiv- 
(a) $C_{\text {CHOCHO }}^{\text {SCIAMACHY }}$

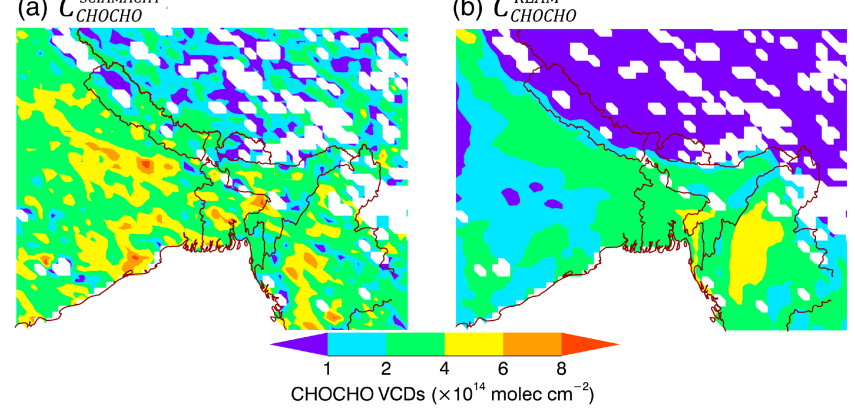

(d) Isoprene contribution to $C_{C H O C H O}^{R E A M}$

(e) Aromatic contribution to $C_{C H O C H O}^{R E A M}$
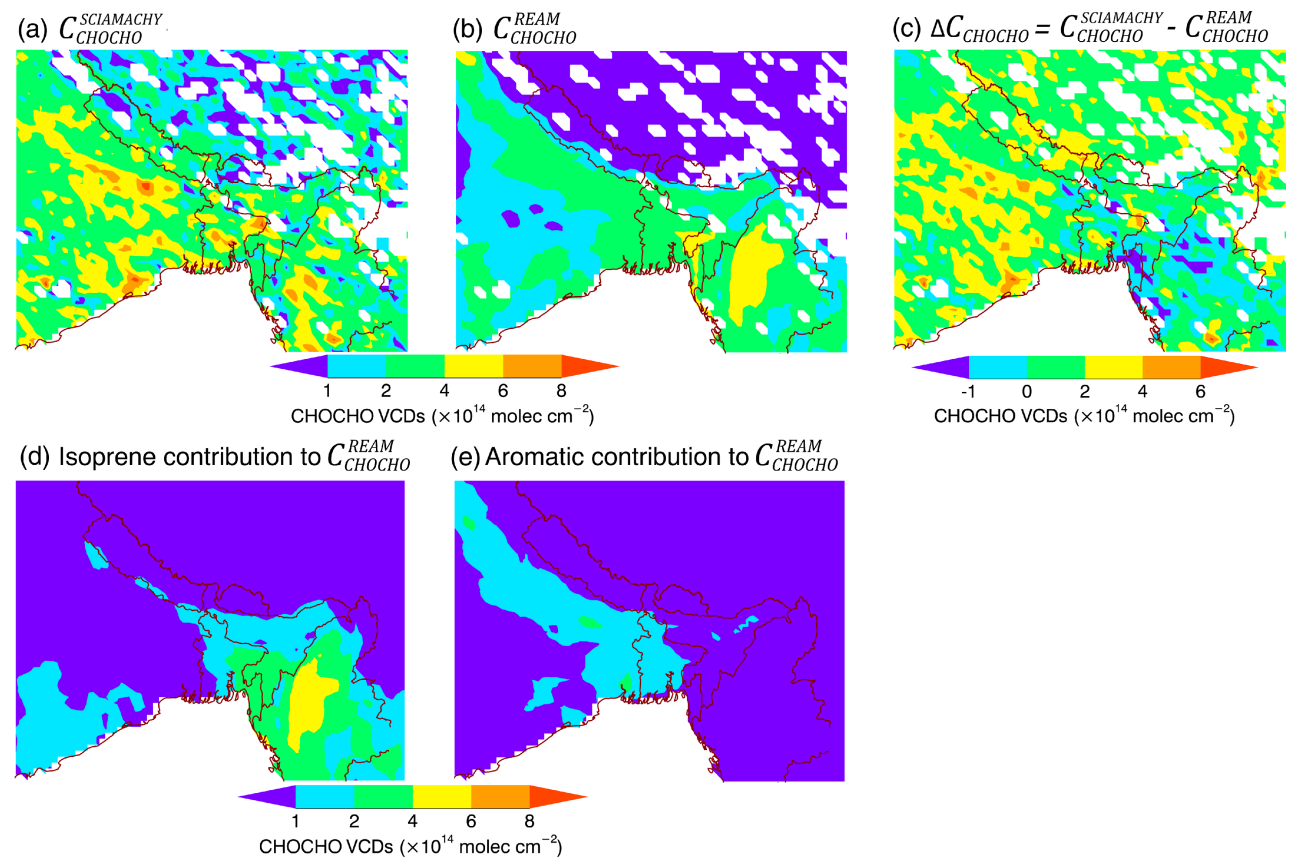

Figure 2. SCIAMACHY-observed CHOCHO VCDs (a), REAM-simulated CHOCHO VCDs (b), the low bias of simulated CHOCHO VCDs (c), simulated isoprene (d), and aromatic (e) contributions to CHOCHO VCDs using the a priori emissions for October 2010. White areas denote missing satellite data or ocean. For each valid SCIAMACHY data point, a corresponding model value is sampled in $(\mathbf{b}, \mathbf{c})$.

ity simulations using the Intercontinental Chemical Transport Experiment-Phase B (INTEX-B) emissions inventory (Zhang et al., 2009; Li et al., 2014), which was developed for the year 2006. We find that, compared to the in situ observations of aromatics, the simulation results using the INTEX$\mathrm{B}$ emissions are better. The main reason for the simulation improvements is the emissions of aromatics in South Asia. Given the large uncertainties in the emissions of aromatics (e.g., Liu et al., 2012b), this result is not surprising. Since MEIC and INTEX-B inventories are developed by the same group, we replace MIX aromatic emissions outside China with INTEX-B data such that aromatic emissions in the model are consistent. The improvements of model simulations compared to in situ observations are shown in Fig. S1 in the Supplement. Since satellite observations are used to improve aromatic emissions (next section), using either MIX or INTEX-B emissions in this work gives the same conclusions. Biogenic VOC emissions are computed with the Model of Emissions of Gases and Aerosols from Nature (MEGAN) algorithm (v2.1; Guenther et al., 2012), and outdoor biomass burning emissions of $\mathrm{CHOCHO}$ and other species are based on Global Fire Emissions Database Version 4.1 with small fires (GFED4.1s; van der Werf et al., 2010; Andreae and Merlet, 2001; Lerot et al., 2010). Indoor burning CHOCHO emissions of India are computed using emission factors from Pettersson et al. (2011) and Li et al. (2014). Rural and urban population distributions of India for the year 2010 are used as spatial proxies (Balk et al., 2006; CIESIN, 2011, 2016).
We adopt the energy consumptions for rural and urban inhabitants on the basis of the National Sample Survey Office of India (NSSO, 2012a, b). Compared with satellite-observed $\mathrm{CO}$ and $\mathrm{NO}_{2}$ VCDs, REAM performs reasonably well in the study region during October 2010 (Fig. S2 in the Supplement). For general model evaluations of REAM, we refer the readers to the papers cited early in this section.

We updated the INTEX-B emission inventory in South Asian countries through inverse modeling constrained by SCIAMACHY CHOCHO VCDs (next section). We run REAM simulations with the a priori and top-down emission inventories, and we compare the results with observations in Sect. 3.1 and 3.2, respectively. We find that some of the model low bias is likely due to emission underestimation. We further carried out three model sensitivity tests to calculate the contributions to surface aromatics from emissions over Tibet, other provinces of China, and South Asia (India and nearby regions). Each simulation is run with only the aromatic emissions from the corresponding region. The $\mathrm{OH}$ concentrations in each simulation are specified to the archived values of the full model simulation. The results for two sub-periods of period 2 are examined in Sect. 3.3.

\subsection{Top-down aromatic emission estimation}

Compared with SCIAMACHY data, REAM using the original emission inventories archived at the overpass time of SCIAMACHY underestimates CHOCHO VCDs in the populated regions of India (Fig. 2). This underestimation is es- 
pecially significant in the Indo-Gangetic Plain located south of the Himalayas (Fig. 2c). We thus derive the top-down aromatic emissions for these regions constrained by SCIAMACHY CHOCHO data (Liu et al., 2012b; Alvarado, 2016).

First, we calculate the difference between observed $\left(C_{\mathrm{CHOCHO}}^{\mathrm{SCIAMACHY}}\right.$, Fig. $\left.2 \mathrm{a}\right)$ and modeled $\left(C_{\mathrm{CHOCHO}}^{\mathrm{REAM}}\right.$, Fig. $\left.2 \mathrm{~b}\right)$ CHOCHO VCDs with original emissions $\left(\triangle C_{\mathrm{CHOCHO}}=\right.$ $C_{\mathrm{CHOCHO}}^{\text {SCIAMACHY }}-C_{\mathrm{CHOCHO}}^{\mathrm{REAM}}$, Fig. $2 \mathrm{c}$ ). This discrepancy greatly exceeds the uncertainties of SCIAMACHY retrieval. We then discuss the potential reasons for the difference, i.e., primary emissions from biomass burning and secondary sources from isoprene, acetylene, ethylene, and aromatics (Fu et al., 2008; Liu et al., 2012b).

Biomass burning is often a major primary source of CHOCHO (Myriokefalitakis et al., 2008). GFED4.1s inventories, as well as fire hot spots observed by MODIS on board the Terra and Aqua satellites, indicate only a small number of fire occurrences during this period in South Asia, with the exception of crop residue burning in Punjab, an agricultural state in north India. The contribution to $\mathrm{CHOCHO}$ VCDs from outdoor biomass burning (Fig. S3a in the Supplement) differs greatly from that of $\Delta C_{\mathrm{CHOCHO}}$ (Fig. 2c), which is large over the industrialized Indo-Gangetic Plain. Simulated indoor burning contribution to CHOCHO VCDs is lower by a factor of about 15 than the CHOCHO VCD discrepancy between satellite retrieval and model simulation (Fig. S3b in the Supplement). The uncertainty of the indoor burning CHOCHO emissions mainly results from that of the emission factor. Even if we assume this uncertainty to be $300 \%$, indoor burning cannot explain the low bias of the simulated CHOCHO VCDs. Therefore, the large model underestimation of CHOCHO over the Indo-Gangetic Plain is unlikely due to outdoor biomass burning or indoor burning during our analysis period.

Direct anthropogenic emissions of $\mathrm{CHOCHO}$ are small (Volkamer et al., 2005; Stavrakou et al., 2009; Liu et al., $2012 b$ ). CHOCHO is produced primarily from the photochemical oxidation of biogenic compounds (e.g., isoprene and terpenes) and hydrocarbon released by anthropogenic activities (e.g., acetylene, ethylene, and aromatics) (Fu et al., 2008). Due to the long atmospheric lifetime of acetylene and ethylene, their contributions to $\mathrm{CHOCHO}$ concentrations are quite small in South Asia during October 2010. The most significant secondary sources of CHOCHO in South Asia are isoprene (Fig. 2d) and aromatics (Fig. 2e). Biogenic isoprene emissions depend on vegetation, sunlight, and temperature. The high isoprene contribution to $\mathrm{CHOCHO}$ VCDs is to the southeast of the Indo-Gangetic Plain, where CHOCHO VCDs are high in both the observations and model simulations. In comparison, aromatic oxidation dominates CHO$\mathrm{CHO}$ over the Indo-Gangetic Plain, where model underestimation is largest (Fig. 2).

We apply the approach by Liu et al. (2012b) to estimate the top-down emissions of aromatics based on SCIAMACHY CHOCHO VCDs. As found by Liu et al. (2012b), domain-

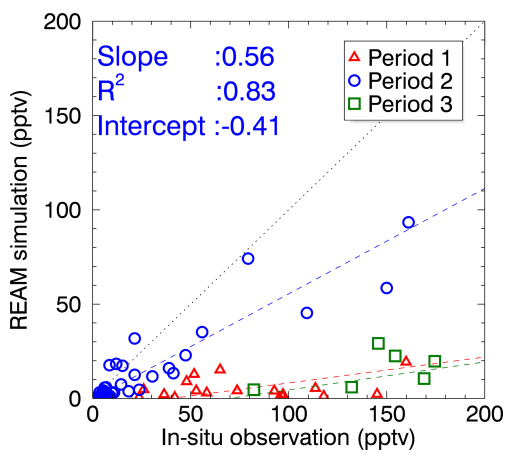

Figure 3. Comparison between REAM-simulated reactive aromatic concentrations ( $y$ axis) and in situ observations ( $x$ axis). REAM results are archived corresponding to the time and location of the observations. Linear regression results for three periods are shown in red (slope $\left.=0.14, R^{2}=0.04\right)$, blue ( and green (slope $=0.15, R^{2}=0.02$ ) dashed lines, respectively.

wide inversion is impractical since model results correlate poorly with gridded satellite data, most likely reflecting the problems in the spatial distribution of a priori emissions. We therefore determine the emissions by inversion for each grid cell at the overpass time of SCIAMACHY as Liu et al. (2012b) and find similar results for India and nearby regions as Liu et al. (2012b) did for eastern China. The topdown biogenic isoprene emissions are essentially the same as the a priori emissions. However, the top-down anthropogenic emissions of aromatics (Fig. S4 in the Supplement) increase by a factor of 2-6. The improved model comparison with in situ observations will be discussed in the next section. One caveat with respect to the top-down emission estimate is that we have to assume that the speciation of aromatics in the a priori emission inventory is correct. Since the purpose of this work is to study transport pathways to the Tibetan Plateau on the basis of in situ observations, we examine lumped reactive aromatics (defined as the sum of toluene, ethyl-benzene, and $\mathrm{m} / \mathrm{p} / \mathrm{o}-\mathrm{xylene}$ ) in the model evaluation (next section). Satellite observations cannot be used for this purpose since $\mathrm{CHO}$ $\mathrm{CHO}$ VCDs over Tibet are below or around the detection limit.

\section{Results and discussion}

\subsection{Observed and simulated reactive aromatics}

The average of observed reactive aromatic surface concentration $(59 \pm 63$ pptv) over the Tibetan Plateau is considerably lower than the values found for megacities of China, such as Beijing (8.04 ppbv) and Shanghai (5.2 ppbv) (Liu et al., 2012b). Higher aromatic levels were measured during period $1(76 \pm 39 \mathrm{pptv})$ and period $3(169 \pm 57 \mathrm{pptv})$ than in period $2(26 \pm 39$ pptv). The model simulation using the a priori emissions in general compares poorly with the in situ 

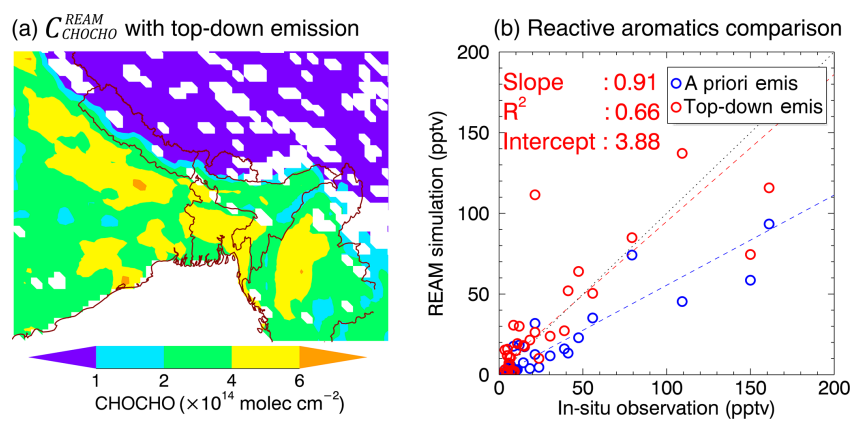

Figure 4. REAM-simulated CHOCHO VCDs with top-down emissions (a) and comparison of simulated and observed reactive aromatic concentrations during period 2 (b). Blue and red circles in panel (b) represent REAM simulation with a priori (slope $=0.56$, $R^{2}=0.83$ ) and with top-down (slope $\left.=0.91, R^{2}=0.66\right)$ emissions, respectively.

observations (Fig. 3). The best performance is during the low-concentration period 2 when the model underestimates the observations by about a factor of 2 . However, the relatively high correlation coefficient $\left(R^{2}=0.83\right)$ suggests that atmospheric transport and emission distribution are reasonably simulated. This is in sharp contrast to periods 1 and 3 when the model underestimates the observations by a factor of 7 with very low correlations between the model and the observations (slope $=0.14$ and $0.15, R^{2}=0.04$ and 0.02 for period 1 and 3 , respectively). We discuss the different reasons for the model performance for periods 1, 2, and 3 in the next three sections.

\subsection{Improvements due to top-down emissions}

Figures 2 and $\mathrm{S} 4$ in the Supplement show that SCIAMACHY observations of CHOCHO suggest much higher industrial emissions of aromatics over the Indo-Gangetic Plain than the a priori emissions. We derive top-down emissions on the basis of SCIAMACHY CHOCHO VCDs (Sect. 2.4). Top-down emissions are higher than the a priori emissions by a factor of 2-6 over the Indo-Gangetic Plain, which is the upwind region of the Tibetan Plateau. Figure 4 shows the resulting improvement in the model simulation. The large underestimations of CHOCHO VCDs over the Indo-Gangetic Plain are corrected as expected (Fig. 4a). At the same time, in situ observations during period 2 are much better reproduced by the model with the slope increasing from 0.56 to 0.91 and a similar $R^{2}$ value (0.66) (Fig. 4b). In contrast, model simulations for periods 1 and 3 are not improved using top-down emission estimates with low biases similar to the original model simulation. This indicates that the reasons for the discrepancies in periods 1 and 3 are probably not related to the uncertainties in emissions but could be linked to deficiencies in model transport in this area.

\section{(a) Oct 19-20}

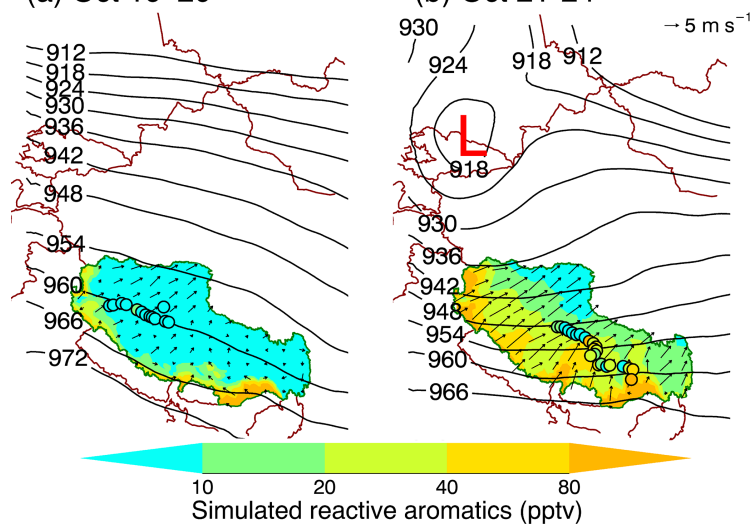

Figure 5. Distributions of WRF-simulated surface wind and REAM-simulated concentrations of reactive aromatics over the Tibetan Plateau during 19-20 October 2010 (a) and 21-24 October 2010 (b). Circles show the observed reactive aromatic concentrations. Composite distributions of simulated reactive aromatic concentrations and surface wind over Tibet, corresponding to sampling time of the observations, are shown in color and by arrows, respectively. Corresponding WRF-simulated $300 \mathrm{hPa}$ geopotential height fields are shown by contour lines. The border of the Tibet Autonomous Region is colored green.

\subsection{Rapid trans-Himalaya transport due to a high-level cut-off low system}

Observed and simulated reactive aromatic concentrations show large variabilities during period 2 (Fig. 4b). An investigation of these data shows that a major contributor is meteorology. Observed concentrations of reactive aromatics during 19-20 October are generally lower $(6.6 \pm 3.4 \mathrm{pptv})$ than those during 21-24 October ( $37 \pm 45$ pptv). The concentration difference during the two time periods is captured by model simulations with top-down emissions (Fig. 5). Analysis of WRF-simulated surface wind speed shows an increase by a factor of 2-4 from 19-20 October (Fig. 5a) to 21-24 October (Fig. 5b), corresponding well to increasing transport of aromatics from the Indo-Gangetic Plain.

To further analyze the difference between the two time periods, we conduct sensitivity simulations as described in Sect. 2.3. We compute the source attributions for emissions over Tibet, India and nearby regions, and China excluding Tibet (Fig. 6). During 19-20 October, reactive aromatics are due to Tibetan emissions. With the exception of one data point, the concentrations are $\leq 7 \mathrm{pptv}$. On 21 October, emissions from India and nearby regions become dominant while the concentrations are still low (7-21 pptv). During 2224 October, however, emissions from India and nearby regions contribute much higher concentrations (10-137 pptv). The only exception is one data point sampled $30 \mathrm{~km}$ east of Lhasa, where about one-fifth of the population of Tibet resides. The contribution of emissions from India and nearby regions to this data point is $\sim 20 \mathrm{pptv}$, still much higher than 


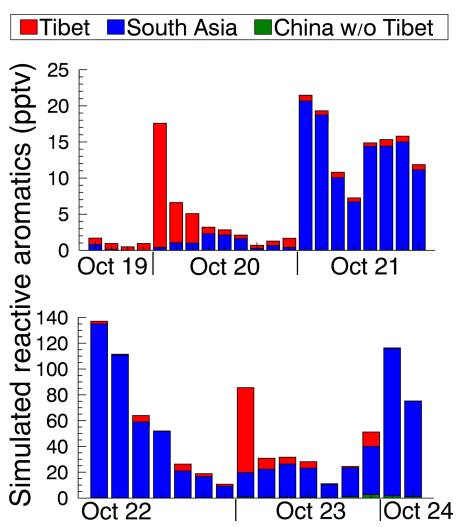

Figure 6. Reactive aromatics emitted from Tibet (red), India and nearby regions ("South Asia", blue), and China excluding Tibet ("China w/o Tibet", green) corresponding to the in situ observations in the REAM simulation with top-down emissions. Contributions from the other regions are negligible.

during 19-20 October. The contribution of emissions from China (excluding Tibet) is negligible $(\sim 1 \%)$ for this period.

The rise of the Tibetan Plateau is a natural barrier for pollution transport (Fig. 1). Considering the high altitude of the Tibetan Plateau, we analyze the $300 \mathrm{hPa}$ geopotential height field in order to understand the change of wind circulation over the region (Fig. 5). During 19-20 October, the upper troposphere shows a northward gradual pressure decrease, which does not promote near-surface forcing of transHimalaya transport (Fig. 5a). During 21-24 October, the presence of a southeastward-moving upper-tropospheric cutoff low system induces increasingly stronger surface wind from India to Tibet (Fig. 5b, Hoskins et al., 1985). The cut-off low system is a closed low-pressure system detached from the westerlies. It began to form on 21 October and started to dissipate on 24 October. Trans-Himalaya air mass flux in the lower atmosphere shows an increase by a factor of 2 to 5 (Fig. S5 in the Supplement). Accompanying this transport, large amounts of pollutants such as reactive aromatics analyzed here are transported to the Tibetan Plateau, leading to much higher surface concentrations.

The cut-off low system provides a more rapid and efficient pollutant transport pathway than transport pathways previously proposed by other studies, such as westerlies (Cong et al., 2015; Ji et al., 2015) and mountain-valley winds (Hindman and Upadhyay, 2002; Dumka et al., 2010). Compared to aromatics, BC is also subject to wet scavenging, which greatly reduces its transport efficiency by convection. Incloud BC scavenging is due to cloud activation or ice nucleation and subsequent removal by precipitation, and belowcloud scavenging is due to collision with rain droplets (e.g., Taylor et al., 2014). During our analysis period, the cut-off low system and the associated precipitation are to the northwest of Tibet (Fig. S6 in the Supplement). Precipitation south (a) Period 1

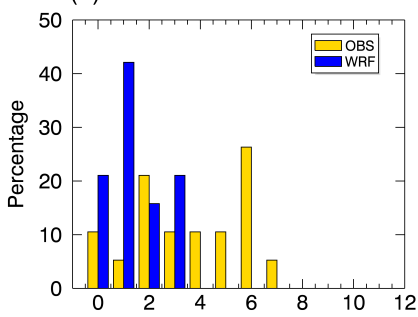

(c) Period 2

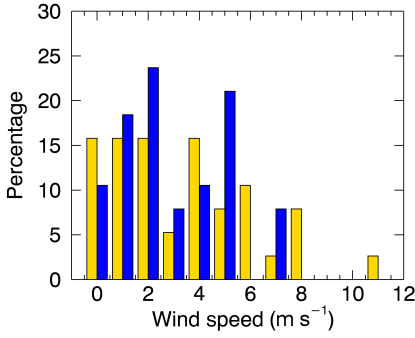

(b) Period 1 under a cut-off low

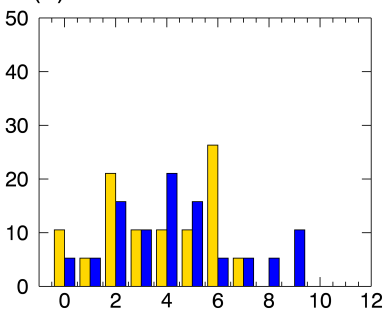

(d) Period 3

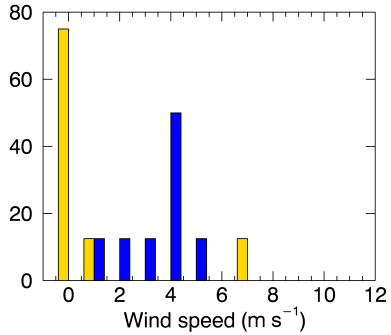

Figure 7. Histograms of observed and simulated surface wind speed for period 1 (a), period 2 (c), and period 3 (d). Panel (b) shows the wind histogram of 23 October with an upper-tropospheric cut-off low system. Model results are sampled at the same time and location as the observations. In (b), the date information is not used. Wind speed is binned at a $1 \mathrm{~m} \mathrm{~s}^{-1}$ interval.

of Tibet is weak, and thus the subsequent removal of BC during trans-Himalaya transport is limited.

To examine the sensitivity of trans-Himalaya transport to the distribution of emission sources, we redistribute the INTEX-B total aromatic emissions over China and other South Asia countries on the basis of the MIX BC emission distributions. We conduct a sensitivity simulation using the redistributed emissions and compare the results to the original simulation. The trans-Himalaya transport from South Asia clearly dominates, and it is strongly affected by the presence of a cut-off low system during our analysis period (Fig. S7 in the Supplement). Our analysis implies that $\mathrm{BC}$ transported in the presence of an upper-tropospheric cutoff low is potentially a major contributor to $\mathrm{BC}$ deposition to Tibetan glaciers.

\subsection{Missing cut-off low system and complex terrain}

Compared to period 2, model performance for periods 1 and 3 is very poor with severe low biases (Fig. 3). Transport deficiency appears to be the main problem. Figure 7 shows the histograms of observed and simulated surface wind speed for the three periods. The observed and simulated wind speed distributions are similar for period 2 (Fig. 7c). In comparison, the simulated wind speed distribution differs drastically for the other two periods (Fig. 7a and d).

The wind speed distributions are more similar between periods 1 and 2 in the observations than model simulations. The underestimation of wind speed in period 1 leads to slower 
transport of pollutants from the Indo-Gangetic Plain and consequently to a low bias in surface reactive aromatics in the model. Examination of the $300 \mathrm{hPa}$ geopotential height field during 13-17 October of period 1 shows a weak trough northeast of Kazakhstan in CSFR reanalysis and WRF simulation results (Fig. S8 in the Supplement). A strong uppertropospheric low-pressure system, akin to the cut-off low system of Fig. 5b, will induce stronger lower-troposphere wind circulation. The lack of radiosonde observations over the interior of the Tibetan Plateau to constrain the meteorological reanalysis is the plausible reason (Fig. S9 in the Supplement). The horizontal scale of the Rossby wave at northern midlatitudes is thousands of kilometers, which can be reasonably represented by the density of the existing radiosonde network. We hypothesize that the smaller-scale cutoff low system, not simulated in the reanalysis, is more likely the reason for the model-observation discrepancy during period 1 . We resample surface wind speed of 23 October, when a cut-off low system leads to rapid trans-Himalaya transport in period 2 as analyzed in the previous section. At the same time of the day and location as the observations, the simulated wind speed histogram is in good agreement with the observations (Fig. 7b). The corresponding air mass flux across the Himalayas would have been much stronger in the presence of a cut-off low system (Fig. S10 in the Supplement).

During period 3 , the observed wind speed histogram is skewed to very low wind speed $\left(0-1 \mathrm{~m} \mathrm{~s}^{-1}\right)$ compared to the simulations (Fig. 7d). Sampling bias to avoid locations with strong wind is a possible reason. Another reason is that these samples were taken at lower altitudes in valleys compared to higher altitudes in the other two periods. Inspection of Fig. 1 shows the complex terrain surrounding the valleys of period 3 sampling. Using high-resolution $(\sim 1 \mathrm{~km})$ terrain data from the US Geological Survey (USGS) Global 30 Arc-Second Elevation (GTOPO30) dataset, we find that the standard deviation of altitude in the $7 \mathrm{~km} \times 7 \mathrm{~km}$ region centered at the corresponding observation location correlates well with the observed reactive aromatics with a $R^{2}$ value of 0.55 (Fig. 8), which suggests that pollution transport is strongly enhanced by the effects of complex terrain. The horizontal resolution of $36 \mathrm{~km}$ used in this study is inadequate to simulate this effect. Model resolution as high as $1 \mathrm{~km}$ appears to be necessary to capture the observed feature, but the computational resource requirement will be exceptionally large for a global model such as that used for CFSR. Other issues related to complex terrains in this region were also discussed by previous studies (Maussion et al., 2011; Ménégoz et al., 2013; He et al., 2014; Kumar et al., 2015). The effects of complex terrain may have also affected the observations of periods 1 and 2 but to a smaller extent since the terrain variation is lower and sampling altitude is higher in those periods.

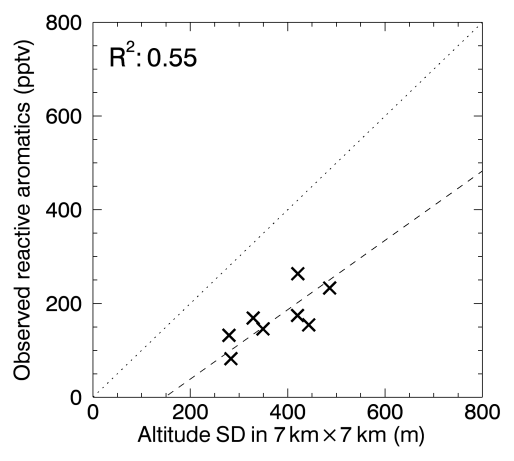

Figure 8. Observed reactive aromatics as a function of terrain complex during period 3 . The latter is computed as the standard deviation of altitude in a $7 \mathrm{~km} \times 7 \mathrm{~km}$ region centered at the sampling location. The dash line denotes a least-squares regression.

\section{Conclusions and implications for climate studies}

We apply the REAM model to analyze in situ observations of reactive aromatics across the Tibetan Plateau. Top-down estimate using SCIAMACHY CHOCHO observations suggests that the a priori inventory for aromatic emissions is low by a factor of 2 to 6 over the industrialized Indo-Gangetic Plain. Application of the top-down emission estimate greatly reduces the low bias of the model during period 2. Model results suggest that the second half of period 2 is characterized by rapid trans-Himalaya transport from India and nearby regions driven by the presence of a cut-off low system in the upper troposphere.

Model performance for periods 1 and 3 is poor compared to period 2, and employing top-down emission estimates does not significantly improve the model simulation of these periods. In situ observations show much stronger surface wind than simulated in the model during period 1 . The lack of radiosonde observations in the interior of the Tibetan Plateau is likely the reason that a cut-off low system, the scale of which is much less than the midlatitude Rossby wave, is not simulated by the T382 $(\sim 38 \mathrm{~km})$ CSFR reanalysis. Consequently, trans-Himalaya transport is greatly underestimated in the model. Sampling of period 3 is in valleys surrounded by complex terrain. Although observed surface wind is weak, we find that reactive aromatic concentrations are strongly correlated with the complexity of surrounding terrain, implying enhanced pollution transport by terrain-driven mixing. Model simulations at a resolution of $36 \mathrm{~km}$ are inadequate for simulating the terrain effect.

The height of the Tibetan Plateau is a natural barrier for pollution transport into this pristine region. This geographical feature is also a challenge for regional and global model simulations. In this study, we use short-lived reactive aromatics as proxies to evaluate model-simulated transport to the Tibetan Plateau on the basis of in situ observations. After correcting for the emission underestimation using satellite observations, simulated trans-Himalaya transport of proxy 
species (using WRF assimilated meteorological fields) still has significant low biases for two reasons: (1) poor representation of a cut-off low system and (2) inadequate representation of terrain effect due to a coarse model resolution. These two transport-related issues likely exist in global climate models; the coarser resolution of climate models than our simulations or CSFR may further worsen the transport biases. Our results imply that pollution transport to the Tibetan Plateau, such as that of $\mathrm{BC}$, is likely to be greatly underestimated in climate models, which has been found previously (e.g., He et al., 2014). In addition to trans-Himalaya transport, $\mathrm{BC}$ emissions, chemical transformation, and wet deposition also require extensive evaluations with the observations over the region. Further analysis of reanalysis and climate model simulations is required to quantify potential model biases and the resulting effect of simulated BC deposition to glaciers on the Tibetan Plateau due to the transport issues we identified in this study.

\section{Data availability}

The modeling data are available at Georgia Institute of Technology website (http://apollo.eas.gatech.edu/data/ trans-Himalaya/). The SCIAMACHY CHOCHO data are available at University of Bremen IUP DOAS website (http://www.iup.uni-bremen.de/doas/glyoxal_data.htm). The NCEP CFSR data are available at University Corporation for Atmophseric Research (UCAR) website (http://rda.ucar. edu/datasets/ds093.0/). The MIX and INTEX-b emission inventories are available at MEIC group website (http:// meicmodel.org). The rural and urban population density data are available at CIESIN website (http://sedac.ciesin. columbia.edu/). The GTOPO30 elevation data are available at USGS website (https://lta.cr.usgs.gov/GTOPO30).

\section{The Supplement related to this article is available online at doi:10.5194/acp-17-3083-2017-supplement.}

Competing interests. The authors declare that they have no conflict of interest.

Acknowledgements. The modeling analysis of this work was supported by the Atmospheric Chemistry Program of the US National Science Foundation. The observation sampling and analysis were supported by the National Natural Science Foundation of China (nos. 41472311, 41273107) and the Special Scientific Research Funds for Environmental Protection Commonwealth Section of China (20603020802L). The contributions of the University of Bremen scientists to this manuscript were funded in part by the University of Bremen as well as the state of Bremen, DLR (German Aerospace), DFG (German Research Foundation), and ESA. Mihalis Vrekoussis acknowledges support from the DFG Research Center/Cluster of Excellence "The Ocean in the Earth System-
MARUM". Leonardo M. A. Alvarado gratefully acknowledges the funding support by the German Academic Exchange Service (DAAD).

Edited by: F. Fierli

Reviewed by: two anonymous referees

\section{References}

Alvarado, L. M. A.: Investigating the role of glyoxal using satellite and MAX-DOAS measurements, $\mathrm{PhD}$ thesis, University of Bremen, available at: http://elib.suub.uni-bremen.de/edocs/ 00105347-1.pdf (last access: 2 August 2016), 2016.

Alvarado, L. M. A., Richter, A., Vrekoussis, M., Wittrock, F., Hilboll, A., Schreier, S. F., and Burrows, J. P.: An improved glyoxal retrieval from OMI measurements, Atmos. Meas. Tech., 7 , 4133-4150, doi:10.5194/amt-7-4133-2014, 2014.

Andreae, M. O. and Merlet, P.: Emission of trace gases and aerosols from biomass burning, Global Biogeochem. Cy., 15, 955-966, doi:10.1029/2000GB001382, 2001.

Atkinson, R.: Atmospheric chemistry of VOCs and $\mathrm{NO}_{x}$, Atmos. Environ., 34, 2063-2101, doi:10.1016/S1352-2310(99)00460-4, 2000.

Balk, D. L., Deichmann, U., Yetman, G., Pozzi, F., Hay, S. I., and Nelson, A.: Determining Global Population Distribution: Methods, Applications and Data, Adv. Parasit., 62, 119-156, doi:10.1016/S0065-308X(05)62004-0, 2006.

Barnett, T. P., Adam, J. C., and Lettenmaier, D. P.: Potential impacts of a warming climate on water availability in snow-dominated regions, Nature, 438, 303-309, doi:10.1038/nature04141, 2005.

Bey, I., Jacob, D. J., Yantosca, R. M., Logan, J. A., Field, B. D., Fiore, A. M., Li, Q. B., Liu, H. G. Y., Mickley, L. J., and Schultz, M. G.: Global modeling of tropospheric chemistry with assimilated meteorology: Model description and evaluation, J. Geophys. Res.-Atmos., 106, 23073-23095, doi:10.1029/2001jd000807, 2001.

Bond, T. C., Bhardwaj, E., Dong, R., Jogani, R., Jung, S., Roden, C., Streets, D. G., and Trautmann, N. M.: Historical emissions of black and organic carbon aerosol from energy-related combustion, 1850-2000, Global Biogeochem. Cy., 21, GB2018, doi:10.1029/2006GB002840, 2007.

Bovensmann, H., Burrows, J. P., Buchwitz, M., Frerick, J., Noël, S., Rozanov, V. V., Chance, K. V., and Goede, A. P. H.: SCIAMACHY: Mission Objectives and Measurement Modes, J. Atmos. Sci., 56, 127-150, 1999.

Burrows, J. P., Hölzle, E., Goede, A. P. H., Visser, H., and Fricke, W.: Earth Observation SCIAMACHY - scanning imaging absorption spectrometer for atmospheric chartography, Acta Astronaut., 35, 445-451, doi:10.1016/0094-5765(94)00278-T, 1995.

Cabrera-Perez, D., Taraborrelli, D., Sander, R., and Pozzer, A.: Global atmospheric budget of simple monocyclic aromatic compounds, Atmos. Chem. Phys., 16, 6931-6947, doi:10.5194/acp16-6931-2016, 2016.

Cagliari, J., Fedrizzi, F., Rodrigues Finotti, A., Echevenguá Teixeira, C., and do Nascimento Filho, I.: Volatilization of monoaromatic compounds (benzene, toluene, and xylenes; BTX) from gasoline: Effect of the ethanol, Environ. Toxicol. Chem., 29, 808-812, doi:10.1002/etc.111, 2010. 
Choi, Y., Wang, Y., Zeng, T., Martin, R. V., Kurosu, T. P., and Chance, K.: Evidence of lightning $\mathrm{NO}_{x}$ and convective transport of pollutants in satellite observations over North America, Geophys. Res. Lett., 32, L02805, doi:10.1029/2004GL021436, 2005.

Choi, Y., Wang, Y., Yang, Q., Cunnold, D., Zeng, T., Shim, C., Luo, M., Eldering, A., Bucsela, E., and Gleason, J.: Spring to summer northward migration of high $\mathrm{O}_{3}$ over the western North Atlantic, Geophys. Res. Lett., 35, L04818, doi:10.1029/2007GL032276, 2008a.

Choi, Y., Wang, Y., Zeng, T., Cunnold, D., Yang, E. S., Martin, R., Chance, K., Thouret, V., and Edgerton, E.: Springtime transitions of $\mathrm{NO}_{2}, \mathrm{CO}$, and $\mathrm{O}_{3}$ over North America: Model evaluation and analysis, J. Geophys. Res.-Atmos., 113, D20311, doi:10.1029/2007jd009632, 2008b.

CIESIN (Center for International Earth Science Information Network, Columbia University), International Food Policy Research Institute, The World Bank, and Centro Internacional de Agricultura Tropical: Global Rural-Urban Mapping Project, Version 1 (GRUMPv1): Population Density Grid, NASA Socioeconomic Data and Applications Center (SEDAC), Palisades, NY, doi:10.7927/H4R20Z93, 2011.

CIESIN (Center for International Earth Science Information Network, Columbia University): Gridded Population of the World, Version 4 (GPWv4): Population Density Adjusted to Match 2015 Revision UN WPP Country Totals, NASA Socioeconomic Data and Applications Center (SEDAC), Palisades, NY, doi:10.7927/H4HX19NJ, 2016.

Cong, Z., Kang, S., Gao, S., Zhang, Y., Li, Q., and Kawamura, K.: Historical Trends of Atmospheric Black Carbon on Tibetan Plateau as Reconstructed from a 150-Year Lake Sediment Record, Environ. Sci. Technol., 47, 2579-2586, doi:10.1021/es3048202, 2013.

Cong, Z., Kawamura, K., Kang, S., and Fu, P.: Penetration of biomass-burning emissions from South Asia through the Himalayas: new insights from atmospheric organic acids, Sci. Rep., 5, 9580, doi:10.1038/srep09580, 2015.

Dumka, U. C., Moorthy, K. K., Kumar, R., Hegde, P., Sagar, R., Pant, P., Singh, N., and Babu, S. S.: Characteristics of aerosol black carbon mass concentration over a high altitude location in the Central Himalayas from multi-year measurements, Atmos. Res., 96, 510-521, doi:10.1016/j.atmosres.2009.12.010, 2010.

Fu, T.-M., Jacob, D. J., Wittrock, F., Burrows, J. P., Vrekoussis, M., and Henze, D. K.: Global budgets of atmospheric glyoxal and methylglyoxal, and implications for formation of secondary organic aerosols, J. Geophys. Res., 113, D15303, doi:10.1029/2007jd009505, 2008.

Gray, B. A., Wang, Y., Gu, D., Bandy, A., Mauldin, L., Clarke, A., Alexander, B., and Davis, D. D.: Sources, transport, and sinks of $\mathrm{SO}_{2}$ over the equatorial Pacific during the Pacific Atmospheric Sulfur Experiment, J. Atmos. Chem., 68, 27-53, doi:10.1007/s10874-010-9177-7, 2011.

Gu, D. S., Wang, Y. H., Smeltzer, C., and Liu, Z.: Reduction in $\mathrm{NO}_{x}$ Emission Trends over China: Regional and Seasonal Variations, Environ. Sci. Technol., 47, 12912-12919, doi:10.1021/es401727e, 2013.

Gu, D., Wang, Y., Smeltzer, C., and Boersma, K. F.: Anthropogenic emissions of $\mathrm{NO}_{x}$ over China: Reconciling the difference of inverse modeling results using GOME-2 and
OMI measurements, J. Geophys. Res.-Atmos., 119, 7732-7740, doi:10.1002/2014JD021644, 2014.

Gu, D., Wang, Y., Yin, R., Zhang, Y., and Smeltzer, C.: Inverse modelling of $\mathrm{NO}_{x}$ emissions over eastern China: uncertainties due to chemical non-linearity, Atmos. Meas. Tech., 9, 5193-5201, doi:10.5194/amt-9-5193-2016, 2016.

Guenther, A. B., Jiang, X., Heald, C. L., Sakulyanontvittaya, T., Duhl, T., Emmons, L. K., and Wang, X.: The Model of Emissions of Gases and Aerosols from Nature version 2.1 (MEGAN2.1): an extended and updated framework for modeling biogenic emissions, Geosci. Model Dev., 5, 1471-1492, doi:10.5194/gmd-51471-2012, 2012.

Hansen, J. and Nazarenko, L.: Soot climate forcing via snow and ice albedos, P. Natl. Acad. Sci. USA, 101, 423-428, doi:10.1073/pnas.2237157100, 2004.

He, C., Li, Q. B., Liou, K. N., Zhang, J., Qi, L., Mao, Y., Gao, M., Lu, Z., Streets, D. G., Zhang, Q., Sarin, M. M., and Ram, K.: A global 3-D CTM evaluation of black carbon in the Tibetan Plateau, Atmos. Chem. Phys., 14, 7091-7112, doi:10.5194/acp14-7091-2014, 2014.

Henze, D. K., Seinfeld, J. H., Ng, N. L., Kroll, J. H., Fu, T.-M., Jacob, D. J., and Heald, C. L.: Global modeling of secondary organic aerosol formation from aromatic hydrocarbons: highvs. low-yield pathways, Atmos. Chem. Phys., 8, 2405-2420, doi:10.5194/acp-8-2405-2008, 2008.

Hindman, E. E. and Upadhyay, B. P.: Air pollution transport in the Himalayas of Nepal and Tibet during the 1995-1996 dry season, Atmos. Environ., 36, 727-739, doi:10.1016/S13522310(01)00495-2, 2002.

Hoskins, B. J., McIntyre, M. E., and Robertson, A. W.: On the use and significance of isentropic potential vorticity maps, Q. J. Roy. Meteor. Soc., 111, 877-946, doi:10.1002/qj.49711147002, 1985.

Ji, Z., Kang, S., Cong, Z., Zhang, Q., and Yao, T.: Simulation of carbonaceous aerosols over the Third Pole and adjacent regions: distribution, transportation, deposition, and climatic effects, Clim. Dynam., 45, 2831-2846, doi:10.1007/s00382-015-2509-1, 2015.

Kang, S., Huang, J., Wang, F., Zhang, Q., Zhang, Y., Li, C., Wang, L., Chen, P., Sharma, C. M., Li, Q., Sillanpää, M., Hou, J., Xu, B., and Guo, J.: Atmospheric Mercury Depositional Chronology Reconstructed from Lake Sediments and Ice Core in the Himalayas and Tibetan Plateau, Environ. Sci. Technol., 50, 2859 2869, doi:10.1021/acs.est.5b04172, 2016.

Kehrwald, N. M., Thompson, L. G., Tandong, Y., MosleyThompson, E., Schotterer, U., Alfimov, V., Beer, J., Eikenberg, J., and Davis, M. E.: Mass loss on Himalayan glacier endangers water resources, Geophys. Res. Lett., 35, L22503, doi:10.1029/2008GL035556, 2008.

Kopacz, M., Mauzerall, D. L., Wang, J., Leibensperger, E. M., Henze, D. K., and Singh, K.: Origin and radiative forcing of black carbon transported to the Himalayas and Tibetan Plateau, Atmos. Chem. Phys., 11, 2837-2852, doi:10.5194/acp-11-28372011, 2011.

Kumar, R., Barth, M. C., Pfister, G. G., Nair, V. S., Ghude, S. D., and Ojha, N.: What controls the seasonal cycle of black carbon aerosols in India?, J. Geophys. Res.-Atmos., 120, 7788-7812, doi:10.1002/2015JD023298, 2015.

Lawrence, M. G. and Lelieveld, J.: Atmospheric pollutant outflow from southern Asia: a review, Atmos. Chem. Phys., 10, 1101711096, doi:10.5194/acp-10-11017-2010, 2010. 
Lerot, C., Stavrakou, T., De Smedt, I., Müller, J.-F., and Van Roozendael, M.: Glyoxal vertical columns from GOME-2 backscattered light measurements and comparisons with a global model, Atmos. Chem. Phys., 10, 12059-12072, doi:10.5194/acp10-12059-2010, 2010.

Li, C., Bosch, C., Kang, S., Andersson, A., Chen, P., Zhang, Q., Cong, Z., Chen, B., Qin, D., and Gustafsson, Ö.: Sources of black carbon to the Himalayan-Tibetan Plateau glaciers, Nat. Commun., 7, 12574, doi:10.1038/ncomms12574, 2016.

Li, M., Zhang, Q., Streets, D. G., He, K. B., Cheng, Y. F., Emmons, L. K., Huo, H., Kang, S. C., Lu, Z., Shao, M., Su, H., Yu, X., and Zhang, Y.: Mapping Asian anthropogenic emissions of nonmethane volatile organic compounds to multiple chemical mechanisms, Atmos. Chem. Phys., 14, 5617-5638, doi:10.5194/acp14-5617-2014, 2014.

Li, M., Zhang, Q., Kurokawa, J.-I., Woo, J.-H., He, K., Lu, Z., Ohara, T., Song, Y., Streets, D. G., Carmichael, G. R., Cheng, Y., Hong, C., Huo, H., Jiang, X., Kang, S., Liu, F., Su, H., and Zheng, B.: MIX: a mosaic Asian anthropogenic emission inventory under the international collaboration framework of the MICS-Asia and HTAP, Atmos. Chem. Phys., 17, 935-963, doi:10.5194/acp17-935-2017, 2017.

Liu, Z., Wang, Y., Gu, D., Zhao, C., Huey, L. G., Stickel, R., Liao, J., Shao, M., Zhu, T., Zeng, L., Liu, S.-C., Chang, C.-C., Amoroso, A., and Costabile, F.: Evidence of Reactive Aromatics As a Major Source of Peroxy Acetyl Nitrate over China, Environ. Sci. Technol., 44, 7017-7022, doi:10.1021/es1007966, 2010.

Liu, Z., Wang, Y., Gu, D., Zhao, C., Huey, L. G., Stickel, R., Liao, J., Shao, M., Zhu, T., Zeng, L., Amoroso, A., Costabile, F., Chang, C.-C., and Liu, S.-C.: Summertime photochemistry during CAREBeijing-2007: $\mathrm{RO}_{x}$ budgets and $\mathrm{O}_{3}$ formation, Atmos. Chem. Phys., 12, 7737-7752, doi:10.5194/acp-12-77372012, 2012a.

Liu, Z., Wang, Y., Vrekoussis, M., Richter, A., Wittrock, F., Burrows, J. P., Shao, M., Chang, C.-C., Liu, S.-C., Wang, H., and Chen, C.: Exploring the missing source of glyoxal (CHOCHO) over China, Geophys. Res. Lett., 39, L10812, doi:10.1029/2012GL051645, 2012b.

Liu, Z., Wang, Y., Costabile, F., Amoroso, A., Zhao, C., Huey, L. G., Stickel, R., Liao, J., and Zhu, T.: Evidence of Aerosols as a Media for Rapid Daytime HONO Production over China, Environ. Sci. Technol., 48, 14386-14391, doi:10.1021/es504163z, 2014.

Lu, Z., Streets, D. G., Zhang, Q., and Wang, S.: A novel backtrajectory analysis of the origin of black carbon transported to the Himalayas and Tibetan Plateau during 1996-2010, Geophys. Res. Lett., 39, L01809, doi:10.1029/2011GL049903, 2012.

Lüthi, Z. L., Škerlak, B., Kim, S.-W., Lauer, A., Mues, A., Rupakheti, M., and Kang, S.: Atmospheric brown clouds reach the Tibetan Plateau by crossing the Himalayas, Atmos. Chem. Phys., 15, 6007-6021, doi:10.5194/acp-15-6007-2015, 2015.

Lutz, A. F., Immerzeel, W. W., Shrestha, A. B., and Bierkens, M. F. P.: Consistent increase in High Asia's runoff due to increasing glacier melt and precipitation, Nature Climate Change, 4, 587592, doi:10.1038/nclimate2237, 2014.

Maussion, F., Scherer, D., Finkelnburg, R., Richters, J., Yang, W., and Yao, T.: WRF simulation of a precipitation event over the Tibetan Plateau, China - an assessment using remote sensing and ground observations, Hydrol. Earth Syst. Sci., 15, 1795-1817, doi:10.5194/hess-15-1795-2011, 2011.
Ménégoz, M., Gallée, H., and Jacobi, H. W.: Precipitation and snow cover in the Himalaya: from reanalysis to regional climate simulations, Hydrol. Earth Syst. Sci., 17, 3921-3936, doi:10.5194/hess-17-3921-2013, 2013.

Menon, S., Hansen, J., Nazarenko, L., and Luo, Y.: Climate Effects of Black Carbon Aerosols in China and India, Science, 297, 2250-2253, doi:10.1126/science.1075159, 2002.

Ming, J., Xiao, C., Cachier, H., Qin, D., Qin, X., Li, Z., and Pu, J.: Black Carbon (BC) in the snow of glaciers in west China and its potential effects on albedos, Atmos. Res., 92, 114-123, doi:10.1016/j.atmosres.2008.09.007, 2009.

Myriokefalitakis, S., Vrekoussis, M., Tsigaridis, K., Wittrock, F., Richter, A., Brühl, C., Volkamer, R., Burrows, J. P., and Kanakidou, M.: The influence of natural and anthropogenic secondary sources on the glyoxal global distribution, Atmos. Chem. Phys., 8, 4965-4981, doi:10.5194/acp-8-4965-2008, 2008.

NSSO: Household Consumption of various Goods and Services in India, (July 2009-June 2010), Vol. KI of 69th round, National Sample Survey Office, Ministry of Statistics \& Programme Implementation, Government of India, 2012a.

NSSO: Energy Sources of Indian Households, (July 2009-June 2010), Vol. KI of 69th round, National Sample Survey Office, Ministry of Statistics \& Programme Implementation, Government of India, 2012b.

Ohara, T., Akimoto, H., Kurokawa, J., Horii, N., Yamaji, K., Yan, X., and Hayasaka, T.: An Asian emission inventory of anthropogenic emission sources for the period 1980-2020, Atmos. Chem. Phys., 7, 4419-4444, doi:10.5194/acp-7-4419-2007, 2007.

Pettersson, E., Boman, C., Westerholm, R., Boström, D., and Nordin, A.: Stove Performance and Emission Characteristics in Residential Wood Log and Pellet Combustion, Part 2: Wood Stove, Energy Fuels, 25, 315-323, doi:10.1021/ef1007787, 2011.

Ramanathan, V. and Carmichael, G.: Global and regional climate changes due to black carbon, Nat. Geosci., 1, 221-227, doi:10.1038/ngeo156, 2008.

Sack, T. M., Steele, D. H., Hammerstrom, K., and Remmers, J.: A survey of household products for volatile organic compounds, Atmos. Environ. A-Gen., 26, 1063-1070, doi:10.1016/09601686(92)90038-M, 1992.

Saha, S., Moorthi, S., Pan, H.-L., Wu, X., Wang, J., Nadiga, S., Tripp, P., Kistler, R., Woollen, J., Behringer, D., Liu, H., Stokes, D., Grumbine, R., Gayno, G., Wang, J., Hou, Y.-T., Chuang, H.Y., Juang, H.-M. H., Sela, J., Iredell, M., Treadon, R., Kleist, D., Van Delst, P., Keyser, D., Derber, J., Ek, M., Meng, J., Wei, H., Yang, R., Lord, S., Van Den Dool, H., Kumar, A., Wang, W., Long, C., Chelliah, M., Xue, Y., Huang, B., Schemm, J.-K., Ebisuzaki, W., Lin, R., Xie, P., Chen, M., Zhou, S., Higgins, W., Zou, C.-Z., Liu, Q., Chen, Y., Han, Y., Cucurull, L., Reynolds, R. W., Rutledge, G., and Goldberg, M.: The NCEP Climate Forecast System Reanalysis, B. Am. Meteorol. Soc., 91, 1015-1057, doi:10.1175/2010BAMS3001.1, 2010.

Singh, P. and Bengtsson, L.: Hydrological sensitivity of a large Himalayan basin to climate change, Hydrol. Process., 18, 23632385, doi:10.1002/hyp.1468, 2004.

Stavrakou, T., Müller, J.-F., De Smedt, I., Van Roozendael, M., Kanakidou, M., Vrekoussis, M., Wittrock, F., Richter, A., and Burrows, J. P.: The continental source of glyoxal estimated by the 
synergistic use of spaceborne measurements and inverse modelling, Atmos. Chem. Phys., 9, 8431-8446, doi:10.5194/acp-98431-2009, 2009.

Taylor, J. W., Allan, J. D., Allen, G., Coe, H., Williams, P. I., Flynn, M. J., Le Breton, M., Muller, J. B. A., Percival, C. J., Oram, D., Forster, G., Lee, J. D., Rickard, A. R., Parrington, M., and Palmer, P. I.: Size-dependent wet removal of black carbon in Canadian biomass burning plumes, Atmos. Chem. Phys., 14, 13755-13771, doi:10.5194/acp-14-13755-2014, 2014.

van der Werf, G. R., Randerson, J. T., Giglio, L., Collatz, G. J., Mu, M., Kasibhatla, P. S., Morton, D. C., DeFries, R. S., Jin, Y., and van Leeuwen, T. T.: Global fire emissions and the contribution of deforestation, savanna, forest, agricultural, and peat fires (19972009), Atmos. Chem. Phys., 10, 11707-11735, doi:10.5194/acp10-11707-2010, 2010.

Volkamer, R., Molina, L. T., Molina, M. J., Shirley, T., and Brune, W. H.: DOAS measurement of glyoxal as an indicator for fast VOC chemistry in urban air, Geophys. Res. Lett., 32, L08806, doi:10.1029/2005GL022616, 2005.

Vrekoussis, M., Wittrock, F., Richter, A., and Burrows, J. P.: Temporal and spatial variability of glyoxal as observed from space, Atmos. Chem. Phys., 9, 4485-4504, doi:10.5194/acp-9-44852009, 2009.

Wang, M., Xu, B., Wang, N., Cao, J., Tie, X., Wang, H., Zhu, C., and Yang, W.: Two distinct patterns of seasonal variation of airborne black carbon over Tibetan Plateau, Sci. Total Environ., 573, 1041-1052, doi:10.1016/j.scitotenv.2016.08.184, 2016.

Wang, X., Gong, P., Sheng, J., Joswiak, D. R., and Yao, T.: Long-range atmospheric transport of particulate Polycyclic Aromatic Hydrocarbons and the incursion of aerosols to the southeast Tibetan Plateau, Atmos. Environ., 115, 124-131, doi:10.1016/j.atmosenv.2015.04.050, 2015.

Wang, Y., Choi, Y., Zeng, T., Ridley, B., Blake, N., Blake, D., and Flocke, F.: Late-spring increase of trans-Pacific pollution transport in the upper troposphere, Geophys. Res. Lett., 33, L01811, doi:10.1029/2005GL024975, 2006.

Wang, Y., Choi, Y., Zeng, T., Davis, D., Buhr, M., Gregory Huey, L., and Neff, W.: Assessing the photochemical impact of snow emissions over Antarctica during ANTCI 2003, Atmos. Environ, 41, 3944-3958, doi:10.1016/j.atmosenv.2007.01.056, 2007.

Wittrock, F., Richter, A., Oetjen, H., Burrows, J. P., Kanakidou, M., Myriokefalitakis, S., Volkamer, R., Beirle, S., Platt, U., and Wagner, T.: Simultaneous global observations of glyoxal and formaldehyde from space, Geophys. Res. Lett., 33, L16804, doi:10.1029/2006g1026310, 2006.

Xu, B., Cao, J., Hansen, J., Yao, T., Joswia, D. R., Wang, N., Wu, G., Wang, M., Zhao, H., Yang, W., Liu, X., and He, J.: Black soot and the survival of Tibetan glaciers, P. Natl. Acad. Sci. USA, 106, 22114-22118, doi:10.1073/pnas.0910444106, 2009.

Yang, Q., Wang, Y., Zhao, C., Liu, Z., Gustafson, W. I., and Shao, M.: $\mathrm{NO}_{x}$ Emission Reduction and its Effects on Ozone during the 2008 Olympic Games, Environ. Sci. Technol., 45, 64046410, doi:10.1021/es200675v, 2011.

Yao, T., Wang, Y., Liu, S., Pu, J., Shen, Y., and Lu, A.: Recent glacial retreat in High Asia in China and its impact on water resource in Northwest China, Sci. China Ser. D, 47, 1065-1075, doi:10.1360/03yd0256, 2004.

Yasunari, T. J., Bonasoni, P., Laj, P., Fujita, K., Vuillermoz, E., Marinoni, A., Cristofanelli, P., Duchi, R., Tartari, G., and Lau,
K.-M.: Estimated impact of black carbon deposition during premonsoon season from Nepal Climate Observatory - Pyramid data and snow albedo changes over Himalayan glaciers, Atmos. Chem. Phys., 10, 6603-6615, doi:10.5194/acp-10-6603-2010, 2010.

Zeng, T., Wang, Y., Chance, K., Browell, E. V., Ridley, B. A., and Atlas, E. L.: Widespread persistent near-surface ozone depletion at northern high latitudes in spring, Geophys. Res. Lett., 30, 2298, doi:10.1029/2003GL018587, 2003.

Zeng, T., Wang, Y., Chance, K., Blake, N., Blake, D., and Ridley, B.: Halogen-driven low-altitude $\mathrm{O}_{3}$ and hydrocarbon losses in spring at northern high latitudes, J. Geophys. Res.-Atmos., 111, D17313, doi:10.1029/2005JD006706, 2006.

Zhang, Q., Streets, D. G., Carmichael, G. R., He, K. B., Huo, H., Kannari, A., Klimont, Z., Park, I. S., Reddy, S., Fu, J. S., Chen, D., Duan, L., Lei, Y., Wang, L. T., and Yao, Z. L.: Asian emissions in 2006 for the NASA INTEX-B mission, Atmos. Chem. Phys., 9, 5131-5153, doi:10.5194/acp-9-5131-2009, 2009.

Zhang, R., Wang, H., Qian, Y., Rasch, P. J., Easter, R. C., Ma, P.L., Singh, B., Huang, J., and Fu, Q.: Quantifying sources, transport, deposition, and radiative forcing of black carbon over the Himalayas and Tibetan Plateau, Atmos. Chem. Phys., 15, 62056223, doi:10.5194/acp-15-6205-2015, 2015.

Zhang, Y. and Wang, Y.: Climate-driven ground-level ozone extreme in the fall over the Southeast United States, P. Natl. Acad. Sci. USA, 113, 10025-10030, doi:10.1073/pnas.1602563113, 2016.

Zhang, Y., Wang, X., Blake, D. R., Li, L., Zhang, Z., Wang, S., Guo, H., Lee, F. S., Gao, B., and Chan, L.: Aromatic hydrocarbons as ozone precursors before and after outbreak of the 2008 financial crisis in the Pearl River Delta region, south China, J. Geophys. Res.-Atmos., 117, D15306, doi:10.1029/2011JD017356, 2012.

Zhang, Y., Wang, Y., Gray, B. A., Gu, D., Mauldin, L., Cantrell, C., and Bandy, A.: Surface and free tropospheric sources of methanesulfonic acid over the tropical Pacific Ocean, Geophys. Res. Lett., 41, 5239-5245, doi:10.1002/2014GL060934, 2014.

Zhang, Y., Wang, Y., Chen, G., Smeltzer, C., Crawford, J., Olson, J., Szykman, J., Weinheimer, A. J., Knapp, D. J., Montzka, D. D., Wisthaler, A., Mikoviny, T., Fried, A., and Diskin, G.: Large vertical gradient of reactive nitrogen oxides in the boundary layer: Modeling analysis of DISCOVER-AQ 2011 observations, J. Geophys. Res.-Atmos., 121, 1922-1934, doi:10.1002/2015JD024203, 2016.

Zhao, C. and Wang, Y.: Assimilated inversion of $\mathrm{NO}_{x}$ emissions over east Asia using $\mathrm{OMI} \mathrm{NO}_{2}$ column measurements, Geophys. Res. Lett., 36, L06805, doi:10.1029/2008GL037123, 2009.

Zhao, C., Wang, Y., Choi, Y., and Zeng, T.: Summertime impact of convective transport and lightning $\mathrm{NO}_{x}$ production over North America: modeling dependence on meteorological simulations, Atmos. Chem. Phys., 9, 4315-4327, doi:10.5194/acp-9-43152009, 2009a.

Zhao, C., Wang, Y., and Zeng, T.: East China Plains: A "Basin" of Ozone Pollution, Environ. Sci. Technol., 43, 1911-1915, doi:10.1021/es8027764, 2009b.

Zhao, C., Wang, Y., Yang, Q., Fu, R., Cunnold, D., and Choi, Y.: Impact of East Asian summer monsoon on the air quality over China: View from space, J. Geophys. Res.-Atmos., 115, D09301, doi:10.1029/2009JD012745, 2010. 
Zhao, Z., Cao, J., Shen, Z., Xu, B., Zhu, C., Chen, L. W. A., Su, X., Liu, S., Han, Y., Wang, G., and Ho, K.: Aerosol particles at a high-altitude site on the Southeast Tibetan Plateau, China: Implications for pollution transport from South Asia, J. Geophys. Res.-Atmos., 118, 11360-11375, doi:10.1002/jgrd.50599, 2013. 